\title{
Evaluation of Antimalarial Activity of
} Hydromethanolic Crude Extract and Solvent Fractions of the Leaves of Nuxia congesta R. Br. Ex Fresen (Buddlejaceae) in Plasmodium berghei Infected Mice

\author{
Melshew Fenta' \\ Wubayehu Kahaliw ${ }^{2}$ \\ 'University of Gondar Specialized \\ Referral Teaching Hospital, University of \\ Gondar, Gondar, Ethiopia; ${ }^{2}$ Department \\ of Pharmacology, School of Pharmacy, \\ College of Medicine and Health Sciences, \\ University of Gondar, Gondar, Ethiopia
}

This article was published in the following Dove Press journal: Journal of Experimental Pharmacology

Background: In Ethiopia, malaria control has been complicated due to resistance of the parasite and its vectors to the current drugs. Therefore, new drugs are required to avert the problem posed by drug-resistant Plasmodium strains. There is need to investigate alternative sources of antimalarial agents and plants are potential source of antimalarial drugs. This study aimed to investigate the antimalarial activity of the leaves of $N$. congesta crude extract (hydromethanolic extract) and solvent fractions (n-hexane, chloroform, and aqueous fractions of crude extract) traditionally used to treat malaria in many parts of Ethiopia.

Methods: Acute oral toxicity of the leaves of $N$. congesta extract was assessed in mice up to a dose of $5,000 \mathrm{mg} / \mathrm{kg}$ body weight. Antiplasmodial activities of crude extract and solvent fractions were assessed in $P$. berghei infected female Swiss albino mice models using the Peter's 4-day suppressive test. The curative activities of crude extract and fractions were evaluated using Rane's test.

Results: Plant extract exhibited no signs of toxicity on mice at a dose of $5,000 \mathrm{mg} / \mathrm{kg}$ body weight. Crude extract showed significant parasitemia suppressions at doses of $500 \mathrm{mg} / \mathrm{kg}$ $(P<0.05), 750 \mathrm{mg} / \mathrm{kg}(P<0.01)$, and $1,000 \mathrm{mg} / \mathrm{kg}(P<0.001)$ as compared to negative control in the Peter's 4-day suppressive test, but failed to reach a significant level at $500 \mathrm{mg} / \mathrm{kg}$ and $750 \mathrm{mg} / \mathrm{kg}$ in the curative test (Rane's test). Aqueous fraction showed significant parasitemia suppression at a dose of $400 \mathrm{mg} / \mathrm{kg}(P<0.05)$ in curative test and $600 \mathrm{mg} / \mathrm{kg}(P<0.05)$ in Peter's 4-day suppressive and curative tests. Maximum suppressive effects of extract $(58.13 \%)$ and aqueous fraction $(44.9 \%)$ were observed at the highest doses administered.

Conclusion: Hydromethanolic leaf extract of $N$. congesta and its aqueous fraction exhibited antimalarial activities. The antimalarial activity and lack of acute toxicity are suggested to uphold the earlier claims made by the Ethiopian traditional practitioners.

Keywords: parasitemia, antimalaria, extract, suppression, curative
Correspondence: Wubayehu Kahaliw Department of Pharmacology, College of Medicine and Health Sciences, University of Gondar, P.O, Box 196, Gondar, Ethiopia $\mathrm{Tel}+251910532412$

Email kahaliw_w@yahoo.com

\section{Introduction}

Malaria is the main widespread disease in tropical and sub-tropical regions of the world affecting humans. ${ }^{1,2}$ It exerts a great economic burden on endemic countries. ${ }^{3}$ Africa is often called the "heartland" of malaria and remains a major public health threat and obstacle to economic development. ${ }^{4}$ According to a World Health 
Organization (WHO) report in 2018, 219 million cases of malaria occurred worldwide in $2017 .^{5}$ In Ethiopia, malaria affects more than $68 \%$ of the population, from which $P$. falciparum accounted for nearly $55 \%$ of all malaria cases in $2013 .^{6}$ According to a report in 2017 , malaria caused an estimated 30,323 deaths and 621,345 new cases in 2015. It accounts for $6 \%$ of malaria cases and $12 \%$ of the cases and deaths due to Plasmodium vivax globally. ${ }^{7}$

Development of resistant strains of Plasmodium, particularly $P$. falciparum to currently available drugs, has posed a great challenge in the treatment and prevention of malaria. ${ }^{8}$

About $70 \%$ of the African population rely on traditional medicine, since affordable conventional medicines are inaccessible. ${ }^{9}$ In rural areas of Ethiopia people resort to use traditional herbal medicine to treat malaria since rural health centers are few and poorly staffed. Traditionally, $N$. congesta is one of the medicinal plants used for treatment of malaria in Sidama district, Ethiopia. ${ }^{10}$

Medicinal plants are a potential source of new antimalarial drugs since they contain a lot of metabolites with a great variety of structures and pharmacological activities. ${ }^{11}$ From previous reports, most medicinal plants which have secondary metabolites in their crude extracts and solvent fractions showed antiplasmodial activities. ${ }^{12}$ N-butanol fraction of Dodonaea angustifolia, ${ }^{13}$ aqueous leaf extracts of Markhamia tomentosa and Polyalthia longifolia, ${ }^{12}$ chloroform extract of Croton macrostachyus, ${ }^{14}$ and Osiris quadripartite ${ }^{15}$ are illustrative examples. Among 40 species of Nuxia $^{16}$ some species are used to treat malaria in Madagascar. ${ }^{17}$ Nuxia oppositijtilia is used to treat malaria, headache, and enlarged spleen and cough, ${ }^{18}$ while $N$. sphaerocephala is used to treat malaria associated splenomegaly in Madagascar. ${ }^{16}$

N. congesta R. Br. ex Fresen (Buddlejaceae), "Atquaro" (Amharic), "Nole" (sidama), and "Common wild elder/brittle wood" (English) is a member of the winter-flowering evergreen small tree or shrub. ${ }^{19}$ Ethnobotanical study showed that $N$. congesta has a wide range of uses. In Ethiopia, the whole leaf part of the plant is used for local beer making. ${ }^{20}$ Fresh leaves, stem bark, and flower part are used for treatment of tonsillitis, dermatological problems, management of rheumatism, and joint swelling $\left({ }^{21,23}-\right)$. In Kenya, the boiled roots of $N$. congesta are used for the treatment of common colds, flu, and abdominal pain. ${ }^{20}$ Bark is used for treatment of indigestion, menstrual problems, and as an expectorant. Bark and leaves are also chewed against indigestion, whereas the ash of leafy twigs in water is used to treat diarrhea. In
Uganda, the bark is used to treat toothache and leaf smoke is used to treat mastitis in cattle. ${ }^{18}$

In many parts of Ethiopia, particularly in Sidama district, the leaf of the plant is used to treat malaria symptoms, with no scientific evidence of its safety or efficacy. This study was designed to assess acute oral toxicity and antimalarial activity of the leaves of $N$. congesta hydromethanolic extract and its solvent fractions in $P$. berghei infected mice.

\section{Materials and Methods \\ Materials}

Plant Material

Fresh leaves of $N$. congesta were harvested from their natural habitat in "Chilga woreda," North Gondar zone, Northwest Ethiopia in January, 2017. Leaves were wrapped with plastic sheets during transport. Plant identification and voucher specimen referencing were done at the Department of Biology herbarium in the College of Natural and Computational Sciences, University of Gondar by a botanist (Mr. Abyu Enyew). The plant specimen was deposited in the University's Herbarium with a voucher number MF 001.

\section{Experimental Animals and Parasite}

Female Swiss albino mice $(23-32 \mathrm{~g})$, obtained from the Department of Pharmacology Animal House, University of Gondar were used for the acute oral toxicity and antiplasmodial activity testing. All experimental animals were housed under standard environmental conditions of temperature at $22-24^{\circ} \mathrm{C}$ under a 12 hour dark-light cycle and allowed free access to drinking water and standard pellet diet. Animal attendants maintained hygiene by constant cleaning and removal of feces from cages every 4 days. Before the actual experiment, animals were acclimatized for 1 week to the experimental environment. The care and handling of the experimental animals was according to the national research council guide for the care and use of laboratory animals. ${ }^{24}$ Ethical approval for the study was obtained from the Department of Pharmacology/University of Gondar Ethics and Research Committee, Gondar, Ethiopia, with reference number SOP4/78/09.

\section{Method}

\section{Extraction}

Fresh leaves of $N$. congesta were washed using tap water, dried under shade, and pulverized to coarse powder using a mortar and pestle. The powder $(1.224 \mathrm{~kg})$ was exhaustively 
macerated in $80 \%$ methanol $(7.2 \mathrm{~L})$ for 72 hours with occasional shaking. Then, it was filtered using a tea sieve and Whatman filter paper No.1 (Whatman, England). The filtrate was kept in a refrigerator at $+4^{\circ} \mathrm{C}$. The residue was re-macerated for 72 hours and this procedure was repeated for the third time. ${ }^{14,25,26}$ The filtrates were combined and concentrated using a rotary evaporator (RE200, Germany) at $45 \mathrm{rpm}$ and $40^{\circ} \mathrm{C}$; then, it was dried using a freeze drier (Ningbo-Scientz-Biotechnology) and the dry product was kept in a desiccator until use. ${ }^{14,27}$

\section{Fractionation}

Antimalarial activity evaluation of the crude extract revealed $N$. congesta methanol extract to have a better activity (section 3.3) and further fractionation was pursued using this plant. The dried extract (160 g) was suspended in distilled water $(800 \mathrm{~mL})$ and then successively partitioned in n-hexane and chloroform using a separatory funnel. The n-hexane and chloroform fractions were concentrated under reduced pressure using a rotary evaporator (RE200, Germany) and dried in an oven at $40^{\circ} \mathrm{C}$ while the aqueous fraction was dried using a freeze drier (Ningbo-ScientzBiotechnology). The dried fractions were placed in a refrigerator at $+4^{\circ} \mathrm{C}$ until use to prevent decomposition. ${ }^{10,23,25}$

\section{Phytochemical Screening}

Eighty percent methanol leaf extract of $N$. congesta was screened for the presence of secondary metabolites using the method described by Azwanida 2015; Fentahun and Makonnen 2017; Fidock 2004. ${ }^{25,28,29}$

\section{Acute Oral Toxicity}

The acute oral toxicity of $N$. congesta leaf extract was evaluated according to the procedures outlined by the Organization for Economic Co-operation and Development (OECD) $425 .^{30}$ The hydromethanolic extract was suspended in a vehicle (distilled water). Following a 3 hour fasting period, eight mice were divided into groups of four (one, one, two, and four mice per group). Extract doses were calculated in reference to the body weight of mice and each mouse was treated with a single oral dose of the extract followed by withholding food for 1 hour. The first group was treated with $2,000 \mathrm{mg} / \mathrm{kg}$ of extract, while the second group was treated with $5,000 \mathrm{mg} / \mathrm{kg}$ followed by observation for any signs of toxicity. Since death was not observed in the first and second groups within 24 hours after administration of the extract, the third and fourth groups were treated with $2,000 \mathrm{mg} / \mathrm{kg}$ and $5,000 \mathrm{mg} / \mathrm{kg}$ N. congesta leaf extract. Mice were observed continuously for 1 hour after administration of the extract; intermittently for 4 hours, over a period of 24 hours and then frequently for 24 hours for 14 days. Gross behavioral changes such as loss of appetite, hair erection, lacrimation, tremors, convulsions, salivation, diarrhea, mortality, and other signs of toxicity manifestation were observed and recorded.

\section{Parasite Infection of Experimental Animals}

The chloroquine sensitive strain of $P$. berghei (strain ANKA) was generously donated by the Ethiopian Public Health Institute, Addis Ababa as cryo-frozen stock of parasitized red blood cells (PRBCs) from female Swiss albino mouse (Mus musculus). The parasite was maintained by serial passage of blood from infected to noninfected mice within 5-6 days of infection. ${ }^{23,31}$ Donors with a parasitemia level of $20-30 \%$ were sacrificed after anesthetizing with ether and blood collected by cardiac puncture into heparinized tubes. The blood was then diluted with phosphate buffered saline (PBS) based on the parasitemia level of each donor and the RBC count of normal mice such that $1 \mathrm{~mL}$ blood contained $5 \times 10^{7}$ parasites. The experimental animals were each treated with $1 \times 10^{7}$ PRBCs by IP injection. The parasite was maintained by transferring parasitized erythrocytes from infected mice to non-infected mice every 5-6 days for the subsequent experiments. ${ }^{23}$

\section{Grouping and Dosing of Animals Suppressive Test}

In order to evaluate the chemosuppressive effect of crude extract, infected mice were randomly assigned to eight groups, each consisting of five mice. Groups I, II, III, IV, $\mathrm{V}$, and VI were orally treated with 100, 200, 400, 500, 750, and $1,000 \mathrm{mg} / \mathrm{kg}$ of $N$. congesta hydroalcoholic leaf extract, respectively, while groups VII and VIII were treated with negative (water; $10 \mathrm{~mL} / \mathrm{kg}$ ) and positive controls (chloroquine; $25 \mathrm{mg} / \mathrm{kg}$ ), respectively. Similarly, 40 mice were randomly divided into eight groups of five each to evaluate chemosuppressive chloroform and n-hexane fractions. Groups I, II, and III were orally treated with 100, 200 , and $400 \mathrm{mg} / \mathrm{kg}$ of chloroform and groups IV, V, and VI were treated with n-hexane fraction. Negative control (3\% T80; $10 \mathrm{~mL} / \mathrm{kg}$ ) and positive control (chloroquine; 25 $\mathrm{mg} / \mathrm{kg}$ ) were administered to groups VII and VIII, respectively. Additionally, to evaluate the aqueous fraction, six groups of infected mice each consisting of five mice were assigned. Groups I, II, III, and IV were treated with 100, 200,400 , and $600 \mathrm{mg} / \mathrm{kg}$ while groups V and VI were 
given negative control (water; $10 \mathrm{~mL} / \mathrm{kg}$ ) and positive control (chloroquine; $25 \mathrm{mg} / \mathrm{kg}$ ), respectively.

\section{Curative Test}

Forty mice were randomly divided into eight groups of five each to evaluate the curative effect of the leaves of $N$. congesta hydromethanolic extract its aqueous fraction. Groups I, II, and III were treated with 500, 750, and $1,000 \mathrm{mg} / \mathrm{kg}$ of hydromethanolic extract and groups IV, $\mathrm{V}$, and VI were treated with 200,400 , and $600 \mathrm{mg} / \mathrm{kg}$ of aqueous fraction. Groups IV and V were treated with negative control (water; $10 \mathrm{~mL} / \mathrm{kg}$ ) and positive control (chloroquine; $25 \mathrm{mg} / \mathrm{kg}$ ), respectively.

\section{Chemosuppressive Test (Peter's 4-Day Suppressive Test)}

To evaluate the chemosuppressive activities of crude extract and solvent fractions in $P$. berghei (ANKA) infected mice the method described by Fidock et $\mathrm{al}^{31}$ and Tarkang et $\mathrm{al}^{32}$ was used.

On the first day (D0), the mice were each infected with $1 \times 10^{7}$ P. berghei. Three hours later, the experimental groups of mice were each treated orally with $10 \mathrm{~mL} / \mathrm{kg}$ of control or extract. Treatment was carried out for 4 consecutive days (D0-D3). The body weight and temperature of each mouse were measured on the first day (D0) and on the fifth day (D4).

On the fifth day (D4), thin blood film was prepared from the tail blood of each experimental animal, fixed in methanol, and stained with Giemsa to reveal parasitized erythrocytes. Parasitemia was determined by using a light microscope with a 100X objective lens, and percent parasitemia was calculated using the following equation: ${ }^{23}$

$$
\% \text { Parasitemia }=\frac{\text { No. of parasitized RBC }}{\text { Total No. of RBC counted }} \times 100
$$

Average percentage chemosuppression was calculated as

$$
\begin{gathered}
\text { Percentage chemosuppression }=100 \\
-\frac{\text { Mean parasitemia (crude extract } / \text { fraction)treated }}{\text { Mean parasitemia(water/T80) control }} \times 100
\end{gathered}
$$

The mean survival time (MST) of the mice in each treatment group was determined over a period of 29 days (D0-D28) as follows; ${ }^{23}$

$$
\text { MST }=\frac{\text { Sum of survival days of all mice in a group }}{\text { Total number of mice in a group }}
$$

\section{Curative Test}

Evaluation of the curative potential of the crude extract and aqueous fraction was carried out in established infection. ${ }^{14,32}$ Forty mice were infected with $P$. berghei $\left(1 \times 10^{7}\right)$ by IP injection on the first day (D0). Seventytwo hours later (D3), the mice were randomly divided into eight groups of five mice each.

Extract, aqueous fraction, and controls were administered once daily for 5 days. Giemsa-stained thin smears were prepared from tail blood samples collected on each day of treatment to monitor the parasitemia level. The body weight and temperature were taken before infection (D0) and from the fourth day (D3) to the eighth day (D7), while the MST of the mice in each treatment group was determined over a period of 29 days (D0-D28) using a formula described in section 2.2.7 above. $^{32,33}$

\section{Determination of Packed Cell Volume in Suppressive and Curative Tests}

Packed cell volume was determined before infection (D0) and after infection (D4) to predict the effectiveness of crude extract and solvent fractions in preventing hemolysis resulting from increasing parasitemia associated with malaria. Heparinized capillary tubes were used for collection of blood from the tail of each mouse. Blood was collected up to $75 \%$ of the volume of the capillary tube (capacity of the capillary tube is $0.1 \mathrm{~mL} ; 0.075 \mathrm{~mL}$ blood) and sealed with clay sealant. The tubes were placed in a micro-hematocrit centrifuge with the sealed end outwards and centrifuged for 10 minutes at 11,000 rpm. The tubes were taken out of the centrifuge, the volume of erythrocytes was measured using a standard Micro-Hematocrit Reader, and PCV was determined as follows. ${ }^{14,34}$

PCV $=\frac{\text { Volume of erythrocytes in a given volume of blood }}{\text { Total blood volume }}$

\section{Statistical Analysis}

Data of the study were presented as mean \pm SEM. Comparisons of parasitemia suppression, body weight, body temperature, and survival time of animals were analyzed using SPSS Windows version 20.0. Statistical significance testing was done by using one-way analysis of variance (ANOVA) followed by Post-hoc Tukey's test. $P$-values of less than 0.05 were considered statistically significant.

\section{Ethical Clearance}

Animals were handled according to the guidelines for care and use of laboratory animals and OECD-guidelines. ${ }^{32}$ Ethical approval for the study was obtained from the Department of Pharmacology/University of Gondar Ethics and Research Committee, Gondar-Ethiopia (SOP4/78/09). 


\section{Results}

\section{Phytochemical Characterization}

Extraction and solvent fractionation of the leaves of N. congesta produced $355 \mathrm{~g}(29 \%), 18.56 \mathrm{~g}(11 \%), 8 \mathrm{~g}(5 \%)$, and $133.6 \mathrm{~g}(83.5 \%)$ of crude extract, chloroform, n-hexane, and aqueous fractions, respectively. Aqueous, chloroform, n-hexane fractions, and crude extract were brown, green, dark green, and dark brown in color, respectively. As indicated in Table 1, phytochemical analysis revealed the presence of saponins, steroids, phenol, flavonoids, cardiac glycosides, terpenoids, and tannins, while alkaloids and anthraquinones are absent.

\section{Acute Oral Toxicity Test}

The leaves of $N$. congesta hydromethanolic extract did not cause any signs of adverse effect and/or mortality at 2,000 and $5,000 \mathrm{mg} / \mathrm{kg}$ oral doses throughout the 14-day study period. Adverse effects (visible behavioral changes) such as hair erection, lacrimation, urination, salivation, weakness, and reduction in their locomotion and feeding activities were not observed within the first 24 hours of extract administration. No significant changes were observed in their body weights. The estimated maximum tolerable dose was above $5,000 \mathrm{mg} / \mathrm{kg}$ body weight for the crude extract tested.

\section{Evaluation of Suppressive Activity of $\mathrm{N}$. Congesta Leaf Extract}

$N$. congesta Leaf Extract showed dose dependent chemosuppressive activity on parasitemia (Table 2, Figures 1 and 2). The effects were statistically significant $(P<0.01)$ at doses of 500 $\mathrm{mg} / \mathrm{kg}, 750 \mathrm{mg} / \mathrm{kg}$, and $1,000 \mathrm{mg} / \mathrm{kg}$ as compared to the negative control. This result showed that the survival times of crude extract treated mice were increased in a dose dependent

Table I Phytochemicals in the Leaves of $N$. Congesta Hydromethanolic Extract. ${ }^{25,28,29}$

\begin{tabular}{|l|l|l|}
\hline $\begin{array}{l}\text { Secondary } \\
\text { Metabolites }\end{array}$ & Types of Test & Results \\
\hline Saponins & Distilled water & + \\
Steroid & $\mathrm{H}_{2} \mathrm{SO}_{4}(10 \mathrm{~mL})+$ chloroform $(10 \mathrm{~mL})$ & + \\
Phenol & Ferric Chloride & + \\
Flavonoids & $\mathrm{NaOH}+\mathrm{H}_{2} \mathrm{SO}_{4}$ & - \\
Cardiac & Glacial acetic acid + ferric chloride + & + \\
glycoside & concentrated $\mathrm{H}_{2} \mathrm{SO}_{4}$ & \\
Terpenoids & $\mathrm{H}_{2} \mathrm{SO}_{4}(3 \mathrm{~mL})+$ chloroform $(2 \mathrm{~mL})$ & + \\
Tannins & Distilled water $+1 \%$ ferric chloride & + \\
Alkaloid & Wagner's, Mayer's reagent & - \\
Anthraquinones & Benzene $+10 \%$ of ammonia hydro-oxide & - \\
\hline
\end{tabular}

Notes: $+=$ present, $-=$ absent. manner although statistical significance was reached at higher doses of $500 \mathrm{mg} / \mathrm{kg}(P<0.05), 750 \mathrm{mg} / \mathrm{kg}$, and $1,000 \mathrm{mg} / \mathrm{kg}$ $(P<0.01)$.

The protection of body weight loss by the crude extract was comparable with the positive control (Chloroquine) at the highest dose $(1,000 \mathrm{mg} / \mathrm{kg})$. Crude extract protected body temperature reduction of mice dose dependently but was not statistically significant as compared to the negative control. Only the positive control showed significant protection in temperature reduction $(P<0.05)$ as compared to the negative control.

\section{Evaluation of Suppressive Activity of $\mathrm{N}$-Hexane, Chloroform, and Aqueous Fractions of $N$. Congesta Leaves}

The aqueous fraction showed a dose dependant parasitemia suppression effect, $16.27 \%, 20.57 \%, 23.34 \%$, and $44.88 \%$ at a dose of $100 \mathrm{mg} / \mathrm{kg}, 200 \mathrm{mg} / \mathrm{kg}, 400 \mathrm{mg} / \mathrm{kg}$, and $600 \mathrm{mg} / \mathrm{kg}$, respectively, while n-hexane and chloroform fractions fail to have this effect (Table 3, Figures 3 and 4). However, significant parasitemia suppression was reached at $600 \mathrm{mg} / \mathrm{kg}$ $(P<0.05)$ as compared to the negative control. All doses of aqueous fraction increased the survival days of mice significantly $(P<0.05)$ as compared to the distilled water treated group. Chloroform fraction showed $15 \%$ parasitemia suppression at $200 \mathrm{mg} / \mathrm{kg}$ and the survival time reached a significant level at this dose as compared to the negative control (T80). The parasitemia suppression effect and prolonged survival were not observed in n-hexane fraction treated groups.

Aqueous fraction exhibited a dose-dependent protection in body weight reduction. In the n-hexane fraction treated groups, there was loss in body weight and body temperature elevation. Chloroform fraction showed dose dependent body weight reduction of experimental animals.

\section{Effect of $N$. Congesta Leaf Extract and Aqueous Fraction on Packed Cell Volume in Suppressive Test}

The effects of the crude extract and aqueous fraction on packed cell volume at day 0 and 4 are presented in Table 4. Crude extract and aqueous fraction of $N$. Congesta showed a dose dependent protection of RBCs from $P$. berghei infection associated hemolysis.

\section{Evaluation of Curative Activity}

The effects of the extract and aqueous fraction on parasitemia suppression, weight, and temperature change mean 
Table 2 Effects of N. Congesta Leaf Extract on Parasite Suppression and Survival Days

\begin{tabular}{|c|c|c|c|c|}
\hline Ex & Dose (mg/kg) & Parasitemia Level & \% Suppression & Survival Days \\
\hline \multirow[t]{3}{*}{ CE } & 100 & $54.8 \pm 0.08 \mathrm{Ib} * * *$ & 2.56 & $7.00 \pm 0.44 \mathrm{~b} * * *$ \\
\hline & 200 & $54.72 \pm 0.88 \mathrm{~b} * * *$ & 4.27 & $7.80 \pm 0.58 \mathrm{~b} * * *$ \\
\hline & 400 & $54.16 \pm 1.52 \mathrm{~b} * * *$ & 4.98 & $7.40 \pm 0.50 \mathrm{~b} * * *$ \\
\hline DW & $10 \mathrm{~mL}$ & $56.24 \pm 2.23 \mathrm{~b} * * *$ & 0 & $5.80 \pm 0.37 \mathrm{~b} * * *$ \\
\hline $\mathrm{CQ}$ & 25 & $0.00 \pm 0.00 \mathrm{a}$ & 100 & $30.00 \pm 0.00 \mathrm{a}^{* * *}$ \\
\hline \multirow[t]{3}{*}{ CE } & 500 & $24.56 \pm 1.55 \mathrm{a} * \mathrm{~b} * * *$ & 41.38 & $8.60 \pm 0.50 \mathrm{a} * \mathrm{~b} * * *$ \\
\hline & 750 & $22.86 \pm 0.55 \mathrm{a}^{* *} \mathrm{~b} * * *$ & 45.44 & $9.00 \pm 0.70 a^{* *} b^{* * *}$ \\
\hline & 1,000 & $17.54 \pm 1.38 \mathrm{a}^{* * *} \mathrm{~b} *$ & 58.13 & $9.40 \pm 0.24 \mathrm{a}^{* *} \mathrm{~b} * * *$ \\
\hline DW & $10 \mathrm{~mL}$ & $41.90 \pm 7.36 \mathrm{~b} * * *$ & 0 & $6.40 \pm 0.40 \mathrm{~b} * * *$ \\
\hline CQ & 25 & $0.00 \pm 0.00 \mathrm{a}^{* * *}$ & 100 & $30.00 \pm 0.00$ \\
\hline
\end{tabular}

Notes: Values are presented as Mean \pm SEM; $n=5$. ${ }^{a}$ compared to the negative control, ${ }^{b}$ compared to the positive control. $* P<0.05, * * P<0.01, * * * P<0.00 I$.

Abbreviations: Ex, Extract; DW, distilled water (negative control); $\mathrm{CQ}$, Chloroquine (positive control); CE, crude extract.

survival time and packed cell volume are presented in compared to the negative control. Aqueous fraction Tables 5 and 6. Crude extract $(1,000 \mathrm{mg} / \mathrm{kg})$ showed sig- $\quad(400 \mathrm{mg} / \mathrm{kg}$, and $600 \mathrm{mg} / \mathrm{kg})$ showed a significant paranificant $(P<0.05)$ reduction in parasitemia level at day 7 sitemia suppression effect $(P<0.05)$ at days $5-7$, but

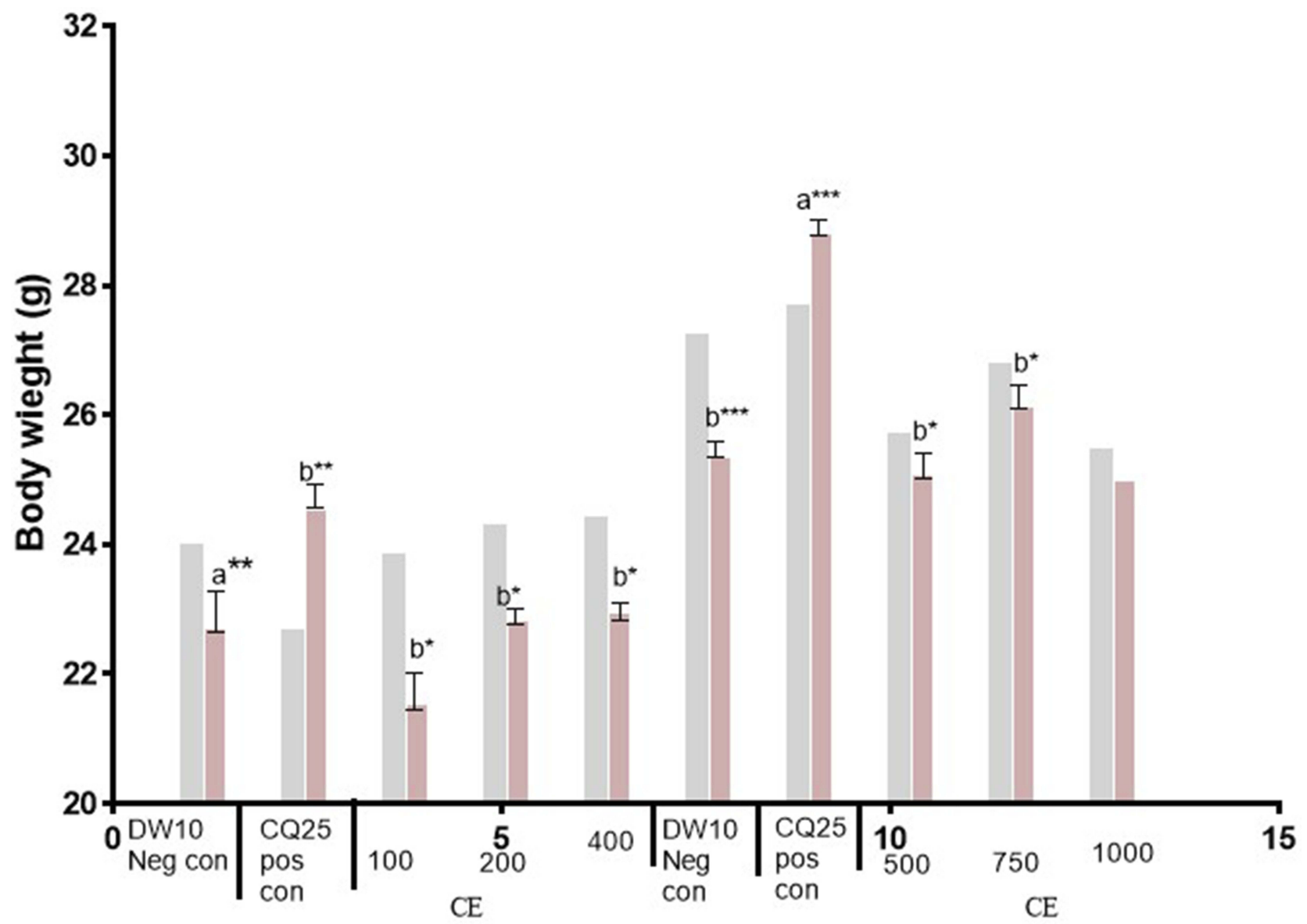

Figure I Body weight (D0 and D4) of Plasmodium infected mice treated with hydromethanolic leaf extract of $\mathrm{N}$. Ccongesta in the 4-day suppressive test. Values are presented as Mean $\pm S E M ; n=5$. Values are significant at $P<0.05$. ${ }^{a}$ compared to the negative control, ${ }^{b}$ compared to the positive control. $* P<0.05, * * P<0.01, * * * P<0.00 I$. $=D 0, \quad=D 4$. Abbreviations: D0, day before infection; D4, fourth day after infection; DWI0 Neg con, Distilled water $10 \mathrm{~mL} / \mathrm{kg} \mathrm{Negative} \mathrm{control;} \mathrm{CQ25} \mathrm{Pos} \mathrm{con,} \mathrm{Chloroquine} 25 \mathrm{mg} / \mathrm{kg}$ Positive control; CE, Crude Extract; 100, 100 mg/kg CE; 200, 200 mg/kg CE; 400, 400 mg/kg CE; 500, 500 mg/kg CE; 750, 750 mg/kg CE; I,000, I,000 mg/kg CE. 


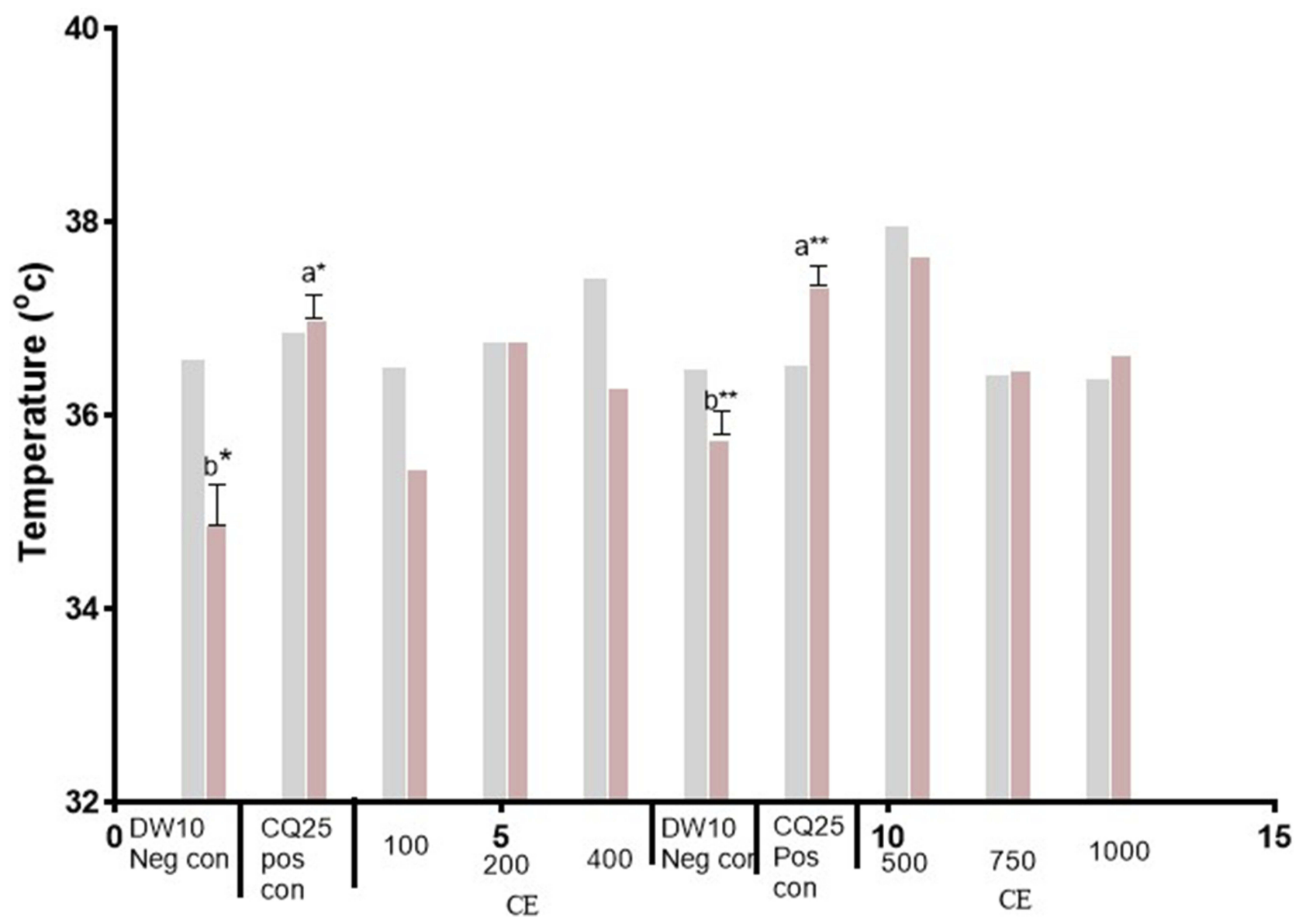

Figure 2 Body temperature (D0 and D4) of Plasmodium infected mice treated with hydromethanolic leaf extract of $N$. congesta in the 4-day suppressive test. Values are presented as Mean \pm SEM; $n=5$, Values are significant at $P<0.05 .{ }^{a}$ compared to the negative control, ${ }^{b}$ compared to positive control. $* P<0.05, * * P<0.01$. $=D 0, \quad=D 4$.

Abbreviations: DWI0 Neg con, Distilled water 10 mL/kg Negative control; CQ25 Pos con, Chloroquine 25 mg/kg Positive control; CE, Crude Extract; 100 , 100 mg/kg CE; 200, $200 \mathrm{mg} / \mathrm{kg}$ CE; 400, $400 \mathrm{mg} / \mathrm{kg}$ CE; 500, $500 \mathrm{mg} / \mathrm{kg}$ CE; 750, $750 \mathrm{mg} / \mathrm{kg}$ CE; I,000, I,000 mg/kg CE; D0, day before infection; D4, fourth day after infection.

extract and aqueous fraction failed to cure infected experimental animals. Only the chloroquine treated group showed total eradication of the established $P$. berghei infection on day 6 .

The apparent survival time difference was not observed between the extract (500 and $750 \mathrm{mg} / \mathrm{kg}$ ) and aqueous fraction $(200$ and $400 \mathrm{mg} / \mathrm{kg}$ ) treated groups and vehicle treated groups. However, at the maximum experimental doses, both the extract and fraction showed a significantly $(P<0.05)$ longer survival days as compared to the negative control. Neither crude extract nor aqueous fraction exhibited significant protection of packed cell volume reduction as compared to the negative control (Table 5).

Extract and aqueous fraction failed to protect body weight and temperature loss at all test concentrations, while chloroquine (positive control) showed significant $(P<0.001)$ body weight and temperature loss protection as compared to the negative control (Table 6).

\section{Discussion}

Management of malaria is a big challenge due to the increasing number of cases of resistance to the majority of currently available drugs, even to new artemisinin-based combination therapy (ACT) drugs, the increasing insecticide resistance of mosquitoes, and the unavailability of effective vaccines and other novel interventions to control the cases. ${ }^{35,36} \mathrm{P}$. falciparum malaria is a life threatening disease if not treated promptly with effective anti-malarial medicines; it can rapidly progress to severe illness and death. ${ }^{8,37}$ So, there is an urgent need to findnew alternative drugs, which have novel modes of action. Therefore, we made an effort to assess antimalarial activity of the leaves of $N$. congesta crude extract and solvent fractions in $P$. berghei infected mice models.

Plants are the main sources of antiprotozoal compounds for the development of drugs against many tropical diseases including malaria. $^{38}$ In Ethiopian society, $N$. 
Table 3 Effects of n-Hexane, Chloroform, and Aqueous Fractions on Parasite Suppression and Survival Days

\begin{tabular}{|c|c|c|c|c|}
\hline $\mathbf{F r}$ & $\begin{array}{l}\text { Dose } \\
\text { (mg/kg) }\end{array}$ & $\begin{array}{l}\text { Parasitemia } \\
\text { Level }\end{array}$ & $\begin{array}{l}\% \\
\text { Suppression }\end{array}$ & Survival Days \\
\hline AQf & 100 & $30.56 \pm 1.85 b^{* * *}$ & 16.27 & $7.60 \pm 0.40 \mathrm{~b} * * *$ \\
\hline DW & 10 & $36.50 \pm 4.0 \mathrm{lb} * * *$ & 0 & $6.60 \pm 0.24 \mathrm{~b} * * *$ \\
\hline CQ & 25 & $0.00 \pm 0.00 a^{* * *}$ & 100 & $30.00 \pm 0.00 \mathrm{a} * * *$ \\
\hline AQf & $\begin{array}{l}200 \\
400 \\
600\end{array}$ & $\begin{array}{l}33.28 \pm 3.87 b^{* * *} \\
32.12 \pm 31.38 b^{* * *} \\
23.10 \pm 1.79 a * b * *\end{array}$ & $\begin{array}{l}20.57 \\
23.34 \\
44.88\end{array}$ & $\begin{array}{l}9.40 \pm 0.60 \mathrm{a} * \mathrm{~b} * * * \\
9.40 \pm 0.92 \mathrm{a} * \mathrm{~b} * * \\
9.80 \\
\pm 0.58 \mathrm{a} * * \mathrm{~b} * * *\end{array}$ \\
\hline DW & 10 & $41.90 \pm 7.36 \mathrm{~b} * * *$ & 0 & $6.40 \pm 0.40 \mathrm{~b} * * *$ \\
\hline $\mathrm{CQ}$ & 25 & $0.00 \pm 0.00 a^{* * *}$ & 100 & $30.00 a^{* * *}$ \\
\hline $\mathrm{Hf}$ & $\begin{array}{l}100 \\
200 \\
400\end{array}$ & $\begin{array}{l}59.40 \pm 1.50 \mathrm{~b} * * * \\
61.80 \pm 6.30 \mathrm{~b} * * * \\
68.20 \pm 5.56 \mathrm{~b} * * *\end{array}$ & $\begin{array}{l}0 \\
0 \\
0\end{array}$ & $\begin{array}{l}6.60 \pm 0.24 b^{* * *} \\
7.40 \pm 0.24 b^{* * *} \\
6.80 \pm 0.24 b * * *\end{array}$ \\
\hline $\mathrm{Cf}$ & $\begin{array}{l}100 \\
200 \\
400\end{array}$ & $\begin{array}{l}63.2 \pm 2.90 \mathrm{~b} * * * \\
47.30 . \pm 3.49 \mathrm{~b} * * * \\
64.00 \pm 6.26 \mathrm{~b} * * *\end{array}$ & $\begin{array}{l}0 \\
15 \\
0\end{array}$ & $\begin{array}{l}7.80 \pm 0.58 \mathrm{~b}^{* * *} \\
8.20 \pm 0.20 \mathrm{a} * \mathrm{~b} * * * \\
7.60 \pm 0.50 \mathrm{~b} * * *\end{array}$ \\
\hline $\begin{array}{l}3 \% \\
\text { T80 }\end{array}$ & 10 & $55.60 \pm 3.97 \mathrm{~b} * * *$ & 0 & $6.00 \pm 0.54 b^{* * * *}$ \\
\hline $\mathrm{CQ}$ & 25 & 0 & 100 & $30.00 \pm 0.00 \mathrm{a}^{* * *}$ \\
\hline
\end{tabular}

Notes: Values are presented as Mean \pm SEM; $n=5$. Values are significant at $P<0.05$, a compared to the negative control, ${ }^{b}$ compared to the positive control. $* P<0.05$, $* * P<0.01$, *** $P<0.001$

Abbreviations: Fr, Fraction; DW, distilled water; 3\%T80 (negative control), 3\% Tween 80; CQ (positive control), chloroquine; AQF, aqueous fraction; CF, chloroform fraction; $\mathrm{Hf}$, n-hexane fraction.

congestais widely used in the treatment of various health problems like malaria, inflammation, rheumatism, joint swelling, tonsillitis, and common cold ${ }^{10,18,20,21}$ and some of Nuxia species have been reported to have in vitro antiplasmodial activity $\left({ }^{39,41}\right)$. The plant's traditional use and phylogenetic information are powerful clues to select a plant for bioactivity screening. ${ }^{32,42}$ By considering the in vitro antimalarial report on other Nuxia species and traditional antimalarial use of $N$. congesta, the in vivo activities of the leaf of $N$. congesta $80 \%$ methanol extract and solvent fractions have been evaluated.

Yield of crude extract of $N$. congesta leaves (29\%) was nearly similar to that of methanolic extracts of a related plant, N. floribunda (20\%). ${ }^{43}$ This high yield of hydromethanolic crude extract of the experimental plant could be due to the high efficiency of methanol in cell walls degradation and hydromethanol could partition a wider polarity range of compounds than pure methanol. In the same case, a higher amount of aqueous fraction was obtained than other fractions. This might be due to the presence of a high concentration of polar compounds in the leaves of the $N$. congesta. ${ }^{15,25}$

As revealed by phytochemical analysis, secondary metabolites (tannins, saponins, terpenoids, and phenols) that have been implicated in antiplasmodial activity of several other plants were also detected in the hydromethanolic leaf extract of $N$. congesta. This is in agreement with data reported by Adugna et $\mathrm{al}^{44}$ in which these and other secondary metabolites have been identified. Most of these metabolites act on biomembranes; for example, saponins have amphiphilic nature, which can complex with cholesterol in biomembranes with their lipophilic moiety and bind to surface glycoproteins and glycolipids. Most of the terpenoids are lipophilic in nature and they readily interact with the lipophilic inner core of the membrane bi-layer. Phenolic compounds, which are present in most herbal medicines, carry one or several hydroxyl functional groups, which can form several hydrogen bonds with electronegative atoms $(\mathrm{O}, \mathrm{N})$ of membrane protein. These lead to alteration of protein structure, impairment of its function, hole and pore formation, which leads to leakage of cell constituents. ${ }^{26,45,46}$

Regarding acute oral toxicity of the experimental plant, a hydromethanolic leaf extract did not cause any overt morbidity and mortality in the experimental mice at $2,000 \mathrm{mg} / \mathrm{kg}$ and $5,000 \mathrm{mg} / \mathrm{kg}$ oral administration. This showed that a lethal dose of $50 \%$ is greater than $5,000 \mathrm{mg} /$ $\mathrm{kg}$, which attests that plant products are frequently considered to be safe and have fewer adverse effects than synthetic ones. ${ }^{37}$

The in vivo antiplasmodial activities of $N$. Congesta crude extract and solvent fractions were investigated by evaluating the chemosuppression during early infection, while crude extract and aqueous fraction were used to evaluate the curative activity of the plant during established infection (Rane's test). In both suppressive and curative tests, determination of percent parasitemia suppression and improved survival days are the most widely used parameters for antiplasmodial activity screening. ${ }^{31,32}$ Since 500,750 , and $1,000 \mathrm{mg} / \mathrm{kg}$ crude extract and 200 , 400 , and $600 \mathrm{mg} / \mathrm{kg}$ aqueous fraction showed significant parasite suppression, they were further evaluated in curative test. ${ }^{47}$ In the 4-day chemosuppressive and Rane's test, the highest parasitemia suppression (100\%) was recorded in the group treated with positive control (chloroquine), while the lowest parasitemia suppression $(0 \%)$ was recorded in the group treated with the negative control, 


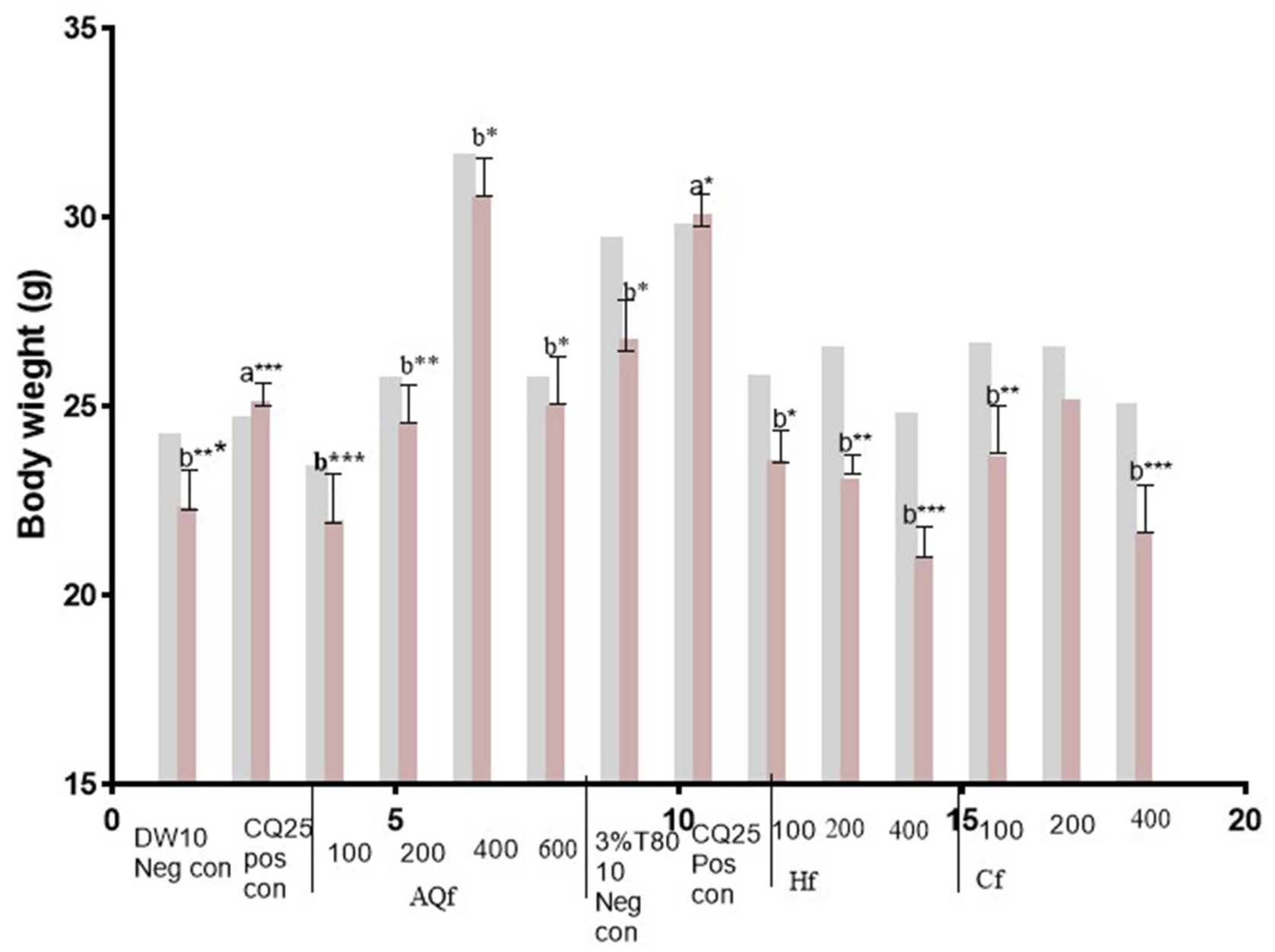

Figure 3 Body weight (D0 and D4) of Plasmodium infected mice treated with hydromethanolic leaf extractsolvent fractions of $N$. congesta in the 4-day suppressive test. Values are significant at $P<0.05,{ }^{\mathrm{a}}$ compared to the negative control, ${ }^{\mathrm{b}}$ compared to the positive control. $* P<0.05,{ }^{* * * P<0.01,} * * * P<0.00 \mathrm{I}$. $=\mathrm{D} 0$, $=\mathrm{D} 4$.

Abbreviations: DWI0 Neg con, Distilled Water 10 mL/kg Negative control; CQ25 Pos con, Chloroquine 25 mg/kg Positive control; $3 \%$ T80 (negative control), $3 \%$ Tween 80; AQf, Aqueous fraction; Hf, n-hexanefraction; Cf, Chloroform fraction; 100, 100 mg/kg AQf/Hf/Cf; 200, 200 mg/kg AQf/Hf/Cf; 400,400 mg/kg AQf/Hf/Cf; D0, day before infection; D4, fourth day after infection.

distilled water. $N$. congesta hydromethanolic extract exhibited dose dependent parasitemia suppression and prolonged the survival days of $P$. berghei infected mice, the highest activity recorded at the maximum dose administered. This is comparable with the activities of the previous reports exhibited by Polyalthia longifolia, Trichilia heudelotii, and melia azedarach. ${ }^{12,27}$ Parasitemia level in all extract and aqueous fraction treated groups was less than the group treated with negative controls. This revealed that extract and its aqueous fraction had a suppressive effect on the multiplication and erythrocyte infectivity of $P$. berghei parasites in mice.

The hydromethanolic leaf extract of $N$. congesta suppressed parasitemia by $58.3 \%$, the highest chemosuppression recorded from all the fractions evaluated in the current study. However, at lower concentrations (100,
$200,400 \mathrm{mg} / \mathrm{kg}$ ), it exhibited insignificant activity as compared to the negative control. This could be attributable to the presence of an insufficient concentration of active principles at lower doses of the extract. ${ }^{15,32}$ The curative activities were significant at $1,000 \mathrm{mg} / \mathrm{kg}$ crude extract at day 7 and 400 and $600 \mathrm{mg} / \mathrm{kg}$ of aqueous fraction at days 5-7.

Crude extract contains a collection of medicinal compounds and activities of one compound may mask the other or may be potentiated, ${ }^{32,46}$ hence, fractionation may help to eliminate potentially toxic, inactivating, and/or potentiating compounds. ${ }^{42}$

Aqueous fraction demonstrated dose dependant higher activity in blood parasitemia suppression against $P$. berghei than other fractions. The relatively higher activity of the aqueous fraction could be due to secondary metabolites present in 


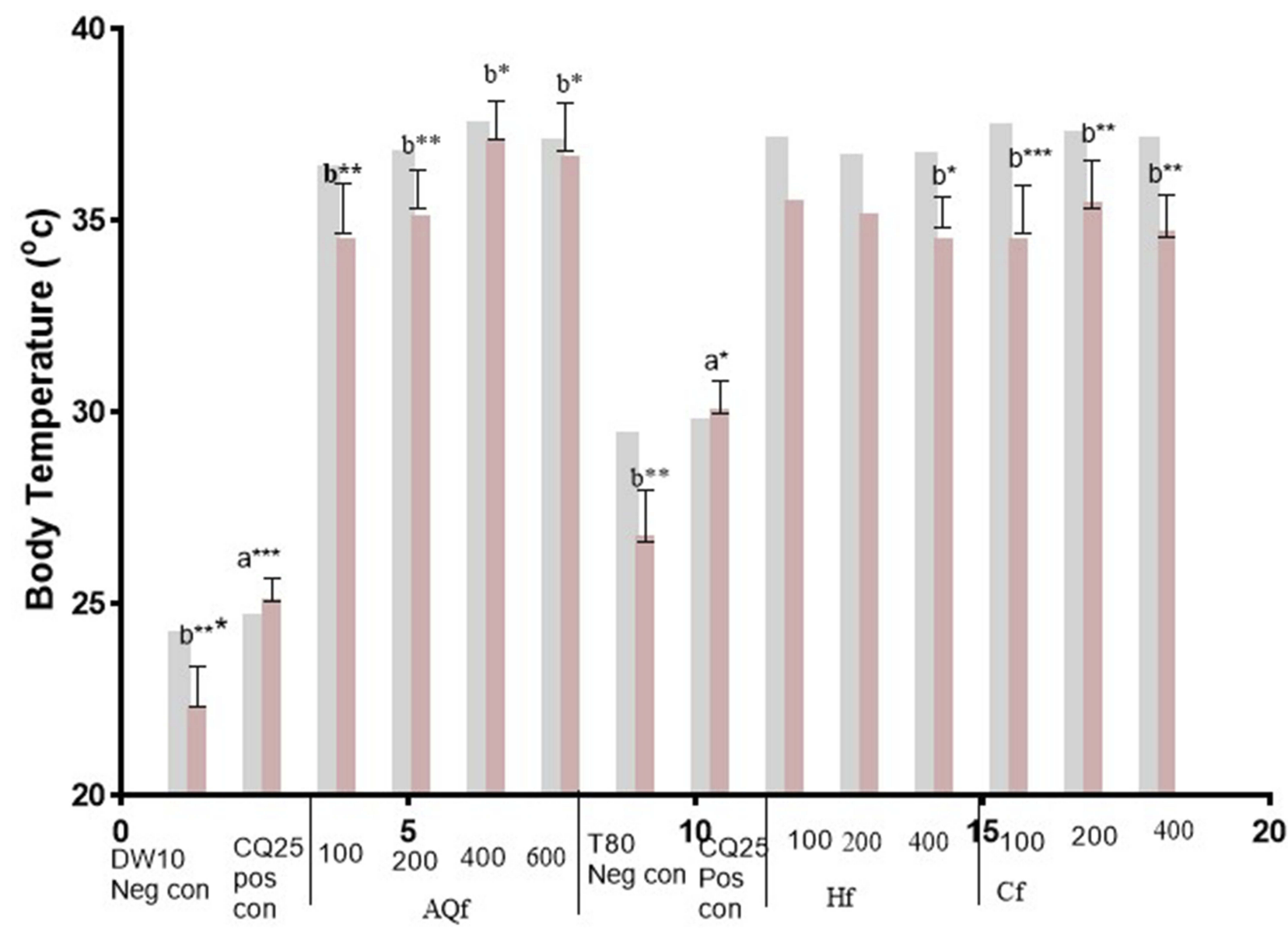

Figure 4 Body temperature (D0 and D4) of Plasmodium infected mice treated with solvent fractions of N. congesta in the 4-day suppressive test. Values are significant at $P<0.05,{ }^{\text {a }}$ compared to the negative control, ${ }^{b}$ compared to the positive control. $* P<0.05, * * P<0.01, * * * P<0.001$. $=D 0, \quad=D 4$.

Abbreviations: DW10 Neg con, Distilled Water $10 \mathrm{~mL} / \mathrm{kg}$ Negative control; CQ25 Pos con, Chloroquine $25 \mathrm{mg} / \mathrm{kg}$ Positive control; $3 \%$ T80 (negative control), 3\%Tween 80; AQf, Aqueous fraction; Hf, n-hexanefraction; Cf, Chloroform fraction; 100, 100 mg/kg AQf/Hf/Cf; 200, 200 mg/kg AQf/Hf/Cf; 400, 400 mg/kg AQf/Hf/Cf; D0, day before infection; D4, fourth day after infection.

crude extract which might be partitioned in the aqueous fraction. ${ }^{32,42}$ A report from the aqueous fraction of Nuxia species confirmed the presence of iridoid glycosides (mono terpenes), ${ }^{19}$ which are water soluble ${ }^{48,49}$ and have antibacterial, anti-inflammatory, ${ }^{50}$ antioxidant, immune modulating, and pain killing properties. ${ }^{49}$ These effects are highly associated with antimalarial activities. ${ }^{34,42,47}$

The MST is a very important parameter to evaluate the antimalarial activity of plant extracts. ${ }^{31}$ The aqueous fraction prolonged the survival time of $P$. berghei infected mice dose dependently. This might be due to the presence of secondary metabolites that prevent the overall pathologic effect of the parasite in the infected mice, like anti-inflammatory, antioxidant effects in addition to suppression of the parasite. ${ }^{51}$

$\mathrm{N}$-hexane fraction did not show any parasitemia inhibition or prolongation of survival days in all dose-treated groups. On the other hand, at higher doses of the fraction the parasitemia level was increased. This could be due to loss of active constituents during fractionation ${ }^{32,42}$ or the constituents partitioned in this fraction may be immunosuppressants which can lower the immune system. ${ }^{17}$

The chloroform fraction did not exhibit dose dependent chemosupressive activity, efficacy diminished as the dose increased. This inconsistent effect might be attributed to constituents in the fraction which may follow different kinetics. $^{52,53}$

In vivo percent mean suppression $\leq 90 \%$ with respect to negative control usually indicates the test compound is active. ${ }^{46}$ Accordingly, crude extract at $1,000 \mathrm{mg} / \mathrm{kg}$ (58.33\%), aqueous fraction at $600 \mathrm{mg} / \mathrm{kg}(44.88 \%)$, and chloroform fraction at $200 \mathrm{mg} / \mathrm{kg}(15 \%)$ could be considered to be active against $P$. berghei. This activity 
Table 4 Activity of the Leaves of $N$. Congesta Extract and Aqueous Fraction on Paced Cell Volume in Suppressive Test

\begin{tabular}{|l|l|l|l|l|}
\hline \multirow{2}{*}{ Ex/Fr } & Dose & \multicolumn{2}{l|}{ PCV } & \\
\cline { 3 - 5 } & $(\mathbf{m g} / \mathbf{k g})$ & $\mathbf{D 0}$ & $\mathbf{D 4}$ & Change \\
\hline AQf & 100 & $55.60 \pm 1.20$ & $44.40 \pm 0.97$ & $-11.20 \pm 0.58 \mathrm{~b} * * *$ \\
\hline DW & $10 \mathrm{~mL}$ & $57.20 \pm 0.86$ & $43.60 \pm 1.02$ & $-13.60 \pm 0.70 \mathrm{~b}^{* * *}$ \\
\hline CQ & 25 & $57.20 \pm 0.85$ & $57.70 \pm 0.85$ & $0.50 \pm 0.60 \mathrm{a}^{* * *}$ \\
\hline AQf & 200 & $56.20 \pm 0.80$ & $51.20 \pm 2.08$ & $-8.83 \pm 3.80$ \\
& 400 & $54.40 \pm 1.77$ & $50.20 \pm 1.59$ & $-7.65 \pm 1.68$ \\
& 600 & $56.60 \pm 1.77$ & $52.40 \pm 1.20$ & $-7.29 \pm 1.35$ \\
\hline CE & 500 & $57.80 \pm 3.27$ & $53.20 \pm 1,59$ & $-6.97 \pm 5.10$ \\
& 750 & $55.40 \pm 0.67$ & $51.60 \pm 1.43$ & $-6.80 \pm 2.87$ \\
& 1000 & $55.00 \pm 2.30$ & $52.40 \pm 1.80$ & $-4.43 \pm 3.03$ \\
\hline DW & $10 \mathrm{~mL}$ & $52.00 \pm 1.04$ & $43.40 \pm 2.15$ & $-16.61 \pm 3.52 b^{* *}$ \\
\hline CQ & 25 & $53.40 \pm 2.69$ & $52.60 \pm 2.37$ & $-1.39 \pm 0.62 \mathrm{a}^{* *}$ \\
\hline
\end{tabular}

Notes: Values are presented as Mean \pm SEM. ${ }^{\text {a }}$ compared to the negative control, b compared to the positive control. Values are significant at $P<0.05$. $* * P<0.01$, $* * * P<0.001$.

Abbreviations: Ex/Fr, Extract/Fraction; CE, Crude Extract; DW, Distilled Water (negative control); CQ (positive control), Chloroquine; D0, Day before infection; D4, Fourth day after infection; AQF, aqueous fraction; PCV, Packed Cell Volume.

could be attributed to a single or a combination of its secondary metabolites.

Temperature and weight reduction are the hallmark of malaria infection in rodent models, indicating that an effective antimalarial agent should prevent temperature and body weight reduction in Plasmodium infected rodents. The dose dependent suppressive activities of the leaves of $N$. congesta crude extract and water fraction proposes that crude extract and water fraction do not have any toxic effects in experimental mice at the doses evaluated. Our acute oral toxicity study result also indicated that the plant extract was found to be safe at the maximum dose tested $(5,000 \mathrm{mg} / \mathrm{kg}){ }^{38}$ However, tremendous body weight loss has been observed in mice treated with $400 \mathrm{mg} / \mathrm{kg}$ of $\mathrm{n}$-hexane and chloroform fractions; this could be attributable to the feed intake depressing effect of metabolites and interfere with the protein digestion by saponins and tannins. ${ }^{54}$

\section{Conclusion}

The methanolic extract and aqueous fraction of $N$. congesta leaves have in vivo anti-malarial activities. The antimalarial activity and lack of acute toxicity is suggested

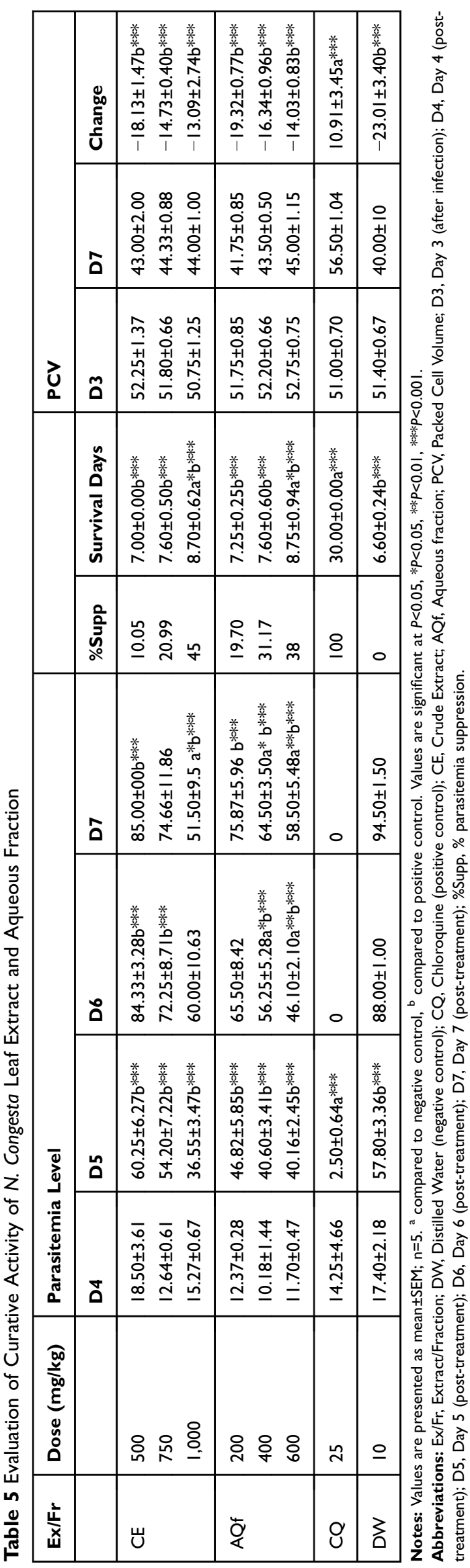




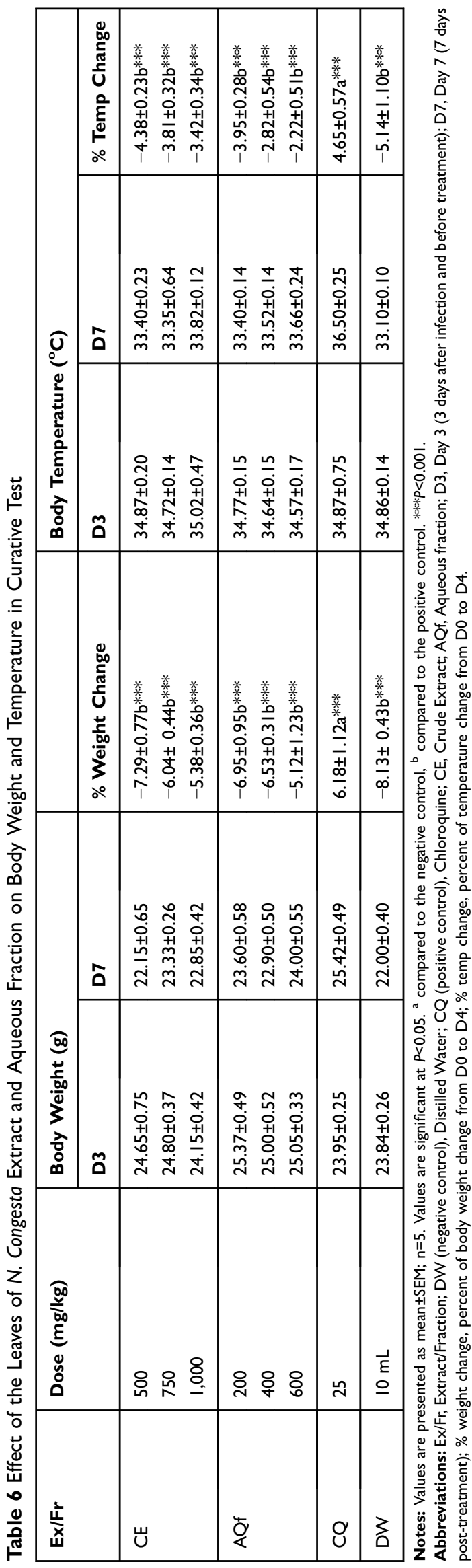

to uphold the earlier claims made by the Ethiopian traditional practitioners.

\section{Abbreviations}

ACT, Artemisinin-based Combination Therapy; ANOVA, Analysis of Variance; OECD, Organization for Economic Cooperation and Development; IP, Intraperitoneal; MST, Mean Survival Time; PBS, Phosphate Buffered Saline; PCV, Packed cell volume; PRBCs, Packed red blood cells; RBC, red blood cell; SEM, Standard Error of Mean; SPSS, Statistical Package for the Social Sciences; WHO, World Health Organization.

\section{Ethics Approval}

All the experiments were conducted in accordance with internationally accepted laboratory animal use, care, and guidelines. Ethical approval for the study was obtained from the Department of Pharmacology/University of Gondar Ethics and Research Committee, Gondar-Ethiopia (SOP4/78/09).

\section{Data Sharing Statment}

Almost all the materials and data of our study are included in the manuscript, some of the material and data will be available to other researchers upon reasonable request.

\section{Acknowledgments}

The authors are thankful to the University of Gondar for Funding the Study.

\section{Authors' Information}

Mss Melshew Fenta (MSc), University of Gondar Specialized Referral Teaching Hospital, University of Gondar, P.O.Box 196, Gondar, Ethiopia, e-mail: melefenta@gmail.com.

\section{Author Contributions}

1. All authors have made substantial contributions in the conception and design, acquisition of data, analysis, and interpretation of data;

2. All authors have made substantial contributions in drafting the article, and revising it critically for important intellectual content;

3. All authors approved the final version the manuscript to be published;

4. All authors have agreed on the work and have given final approval of the version to be published. 


\section{Funding}

The source of funding for this research is the University of Gondar.

\section{Disclosure}

The authors have no conflict of interest to disclose.

\section{References}

1. Iwuafor AA, Egwuatu CC, Nnachi AU, et al. Malaria. parasitemia and the use of insecticide-treated nets (INTs) for malaria control amongst under-5 year old children in Calabar, Nigeria. BMC Infect Dis. 2016;16. doi:10.1186/s12879-016-1459-5

2. Che P, Cui L, Kutsch O, Cui L, Li Q. Validating a firefly luciferasebased high-throughput screening assay for antimalarial drug discovery. Assay Drug Dev Technol. 2012;10(1):61-68. doi:10.1089/ adt.2011.0378

3. Doolan DL. Plasmodium Immunomics. Int J Parasitol. 2011;41 (1):3-20. doi:10.1016/j.ijpara.2010.08.002

4. Snow RW, Amratia P, Kabaria CW, Noor AM, Marsh K. The changing limits and incidence of malaria in Africa: 1939-2009. Adv Parasitol. 2012;78:169-262.

5. World Health Organization. World Malaria Report. 2018. Available from: https://apps.who.int>iris >bitstream>handle>9789241565653-eng. Accessed October 20, 2019.

6. Aregawi M, Lynch M, Bekele W, et al. Time series analysis of trends in malaria cases and deaths at hospitals and the effect of antimalarial interventions, 2001-2011, Ethiopia. PLoS One. 2014;9:11. doi:10.1371/journal.pone. 0106359

7. Deribew A, Dejene T, Kebede B. Incidence, prevalence and mortality rates of malaria in Ethiopia from 1990 to 2015: analysis of the global burden of diseases 2015. Malar J. 2017;16:271. doi:10.1186/s12936-0171919-4

8. Cui L, Mharakurwa S, Ndiaye D, Rathod PK, Rosenthal PJ. Antimalarial drug resistance: literature review and activities and findings of the ICEMR network. Am J Trop Med Hyg. 2015;93 (3):57-68. doi:10.4269/ajtmh.15-0007

9. Murithi CK, Fidahusein DS, Nguta JM, Lukhoba CW. Antimalarial activity and in vivo toxicity of selected medicinal plants naturalised in Kenya. Int Educ Res J. 2014;2:395-406.

10. Asnake S, Teklehaymanot T, Hymete A, Erko B, Giday M. Survey of medicinal plants used to treat malaria by Sidama People of Boricha District, Sidama Zone, South Region of Ethiopia. Evid Based Complement Alternat Med. 2016;2016:1-9. doi:10.1155/2016/9690164

11. Ntie-Kang F, Onguéné PA, Lifongo LL, Ndom JC, Sippl W, Mbaze LM. The potential of anti-malarial compounds derived from African medicinal plants, part ii: a pharmacological evaluation of non-alkaloids and non-terpenoids. Malaria J. 2014;13:81. doi:10.1186/14752875-13-81

12. Bankole AE, Adekunle AA, Sowemimo AA, Umebese CE, Abiodun O, Gbotosho GO. Phytochemical screening and in vivo antimalarial activity of extracts from three medicinal plants used in malaria treatment in Nigeria. Parasitol Res. 2016;115:299-305. doi:10.1007/s00436-0154747-x

13. Amelo W, Nagpal P, Makonnen E. Antiplasmodial activity of solvent fractions of methanolic root extract of Dodonaea angustifolia in $P$. berghei infected mice. BMC Complement Altern Med. 2014;14 (1):462. doi:10.1186/1472-6882-14-462

14. Bantie L, Assefa S, Teklehaimanot T, Engidawork E. In vivo antimalarial activity of the crude leaf extract and solvent fractions of Croton macrostachyus Hocsht. (Euphorbiaceae) against $P$. berghei in Mice. BMC Complement Altern Med. 2014;14:79. doi:10.1186/14726882-14-79
15. Girma S, Giday M, Erko B, Mamo H. Effect of Crude Leaf Extract of Osyris quadripartita on P. berghei in Swiss Albino Mice. BMC Complement Altern Med. 2015;15(1):184.

16. Al-Massarani SM, El-Gamal AA, Parvez MK, et al. New cytotoxic seco-type triterpene and labdane-type diterpenes from Nuxia oppositifolia. Molecules. 2017;22(3):389. doi:10.3390/ molecules 22030389

17. Neergheen-Bhujun VS. Underestimating the toxicological challenges associated with the use of herbal medicinal products in developing countries. Biomed Res Int. 2013;2013.

18. Oyen LFA, Radlk L Protologue report British association advancem science. 1885: 1081. Available from: www.itto.int/files/itto_project_ db_input/2595//E-PD-479-07-R2-M-Timbers-2-5.pdf. AccessedNovember 30, 2019.

19. Jensen SR, Ravnkilde L, Schripsema J. Unedoside derivatives in nuxia and their biosynthesis. Phytochemistry. 1998;47(6):10071011. doi:10.1016/S0031-9422(98)80062-9

20. Kipkore W, Wanjohi B, Rono H, Kigen G. A Study of the medicinal plants used by the Marakwet community in Kenya. J Ethnobiol Ethnomed. 2014;10:24. doi:10.1186/1746-4269-10-24

21. Bussmann RW, Swartzinsky P, Worede A, Evangelista P. Plant use in Odo-Bulu and Demaro, Bale region, Ethiopia. J Ethnobiol Ethnomed. 2011;7:28. doi:10.1186/1746-4269-7-28

22. Chekole G, Asfaw Z, Kelbessa E. Ethnobotanical study of medicinal plants in the environs of tara-gedam and amba Remnant forests of Libo Kemkem District, Northwest Ethiopia. J Ethnobiol Ethnomed. 2015;11(1):4

23. Fenetahun Y, Eshetu G. A review on ethnobotanical studies of medicinal plants use by agro-pastoral communities in, Ethiopia. $J$ Med Plants. 2017;5(1):33-44.

24. Council NR. Guide for the Care and Use of Laboratory Animals. National Academies Press; 2010.

25. Tiwari P, Kumar B, Kaur M, Kaur G, Kaur H. Phytochemical screening and extraction: a review. Int Pharm Sci. 2011;1(1):98-106.

26. Azwanida N. A review on the extraction methods use in medicinal plants, principle, strength and limitation. Med Aromat Plants. 2015;4 (196):2167-2412.

27. Asnake S, Teklehaymanot T, Hymete A, Erko B, Giday M. Evaluation of the antiplasmodial properties of selected plants in Southern Ethiopia. BMC Complement Altern Med. 2015;15(1):448.

28. Cathrine L, KS B. General techniques involved in phytochemical analiysis. Int $J$ Adv Res Chem Sci. 2015;2:4.

29. Evans WC. Trease and Evans' Pharmacognosy. Elsevier Health Sciences; 2009.

30. OECD. Acute Oral Toxicity - Up-And-Down-Procedure (UDP). OECD Guidelines for the Testing of Chemicals. OECD Publishing Paris; 2008:425

31. Fidock DA, Rosenthal PJ, Croft SL, Brun R, Nwaka S. Antimalarial drug discovery: efficacy models for compound screening. Nat Rev Drug Discov. 2004;3(6):509-520. doi:10.1038/nrd1416

32. Tarkang PA, Appiah-Opong R, Ofori MF, Ayong LS, Nyarko AK. Application of multi-target phytotherapeutic concept in malaria drug discovery: a systems biology approach in biomarker identification. Biomark Res. 2016;4(1):25.

33. Arrey Tarkang P, Okalebo FA, Ayong LS, Agbor GA, Guantai AN. Anti-malarial activity of a polyherbal product (nefang) during early and established plasmodium infection in rodent models. Malaria J. 2014;13(1):456.

34. Somsak V, Polwiang N, Chachiyo S. In vivo antimalarial activity of annona muricata leaf extract in mice infected with Plasmodium berghei. J Pathog. 2016;2016.

35. Beeson JG, Drew DR, Boyle MJ, Feng G, Fowkes FJ, Richards JS. Merozoite surface proteins in red blood cell invasion, immunity and vaccines against malaria. FEMS Microbiol Rev. 2016;40(3):343-372. doi:10.1093/femsre/fuw001 
36. Pérez-Moreno G, Cantizani J, Sánchez-Carrasco P, et al. Discovery of new compounds active against Plasmodium falciparum by high throughput screening of microbial natural products. PLoS One. 2016;11(1):e0145812. doi:10.1371/journal.pone.0145812

37. Gabryszewski SJ, Dhingra SK, Combrinck JM, et al. Evolution of fitness cost-neutral mutant PfCRT conferring P. falciparum 4-aminoquinoline drug resistance is accompanied by altered parasite metabolism and digestive vacuole physiology. PLoS Pathog. 2016;12(11): e1005976. doi:10.1371/journal.ppat.1005976

38. Lima RBS, Rocha e Silva LF, Melo MRS, et al. In vitro and in vivo anti-malarial activity of plants from the Brazilian amazon. Malaria J. 2015;14(1):508.

39. Batista R, De Jesus Silva A Jr, De Oliveira AB. Plant-derived antimalarial agents: new leads and efficient phytomedicines. part II. nonalkaloidal natural products. Molecules. 2009;14(8):3037-3072. doi:10.3390/molecules14083037

40. Mambu L, Grellier P, Florent L, et al. Clerodane and labdane diterpenoids from Nuxia sphaerocephala. Phytochemistry. 2006;67 (5):444-451. doi:10.1016/j.phytochem.2005.11.024

41. Amoa Onguéné P, Ntie-Kang F, Lifongo LL, Ndom JC, Sippl W, Mbaze LM. The potential of anti-malarial compounds derived from african medicinal plants, part I: a pharmacological evaluation of alkaloids and terpenoids. Malaria J. 2013;12:449. doi:10.1186/ 1475-2875-12-449

42. Rasoanaivo P, Wright CW, Willcox ML, Gilbert B. Whole plant extracts versus single compounds for the treatment of malaria: synergy and positive interactions. Malaria J. 2011;10(1):54. doi:10.1186/1475-2875-10-S1-S4

43. Boaduo NKK. Evaluation of six plant species used traditionally in the treatment and control of diabetes mellitus. University of Pretoria; 2010.

44. Adugna M, Feyera T, Taddese W and Admasu P. In vivo antimalarial activity of crude extract of aerial part of artemisia abyssinica against plasmodium berghei in Mice. Global J Pharmacol. 2014;8(4):557565 .
45. Chikezie PC, Ibegbulem CO, Mbagwu FN. Medicinal potentials and toxicity concerns of bioactive principles. Med Aromat Plants. 2015;4 (3):1-15.

46. Roth M, Araya JJ, Timmermann BN, Hagenbuch B. Isolation of modulators of the liver-specific organic anion-transporting polypeptides (OATPs) 1B1 and 1B3 from Rollinia emarginata Schlecht (annonaceae). J Pharmacol Exp Ther. 2011;339(2):624-632. doi:10.1124/jpet.111.184564

47. Jensen SR. Chemistry of buddlejaceae. New World Buddlejaceae Fl Neotrop Monogr. 2000;81:42-61.

48. Radev R. Pharmacological effects of phenylethanoid glycosides. $J$ Clin Med. 2010;2:20-23.

49. Wink M. Modes of action of herbal medicines and plant secondary metabolites. Medicines. 2015;2(3):251-286. doi:10.3390/medicines 2030251

50. Kefe A, Giday M, Mamo H, Erko B. Antimalarial properties of crude extracts of seeds of Brucea antidysenterica and leaves of Ocimum lamiifolium. In: BMC Complementary and Alternative Medicine. 2016:16.

51. Toma A, Deyno S, Fikru A, Eyado A, Beale A. In vivo antiplasmodial and toxicological effect of ethanol extract of echinops kebericho traditionally used in treatment of malaria in Ethiopia. Malaria. 2015;14(1):196.

52. Jonville M, Kodja H, Humeau L, et al. Screening of medicinal plants from reunion island for antimalarial and cytotoxic activity. J Ethnopharmacol. 2008;120(3):382-386. doi:10.1016/j.jep.2008.09.005

53. Jonville M, Kodja H, Strasberg D, et al. Antiplasmodial, anti-inflammatory and cytotoxic activities of various plant extracts from the mascarene archipelago. J Ethnopharmacol. 2011;136(3):525-531. doi:10.1016/j.jep.2010.06.013

54. Alli LA, Adesokan AA, OA S. Antimalarial activity of fractions of aqueous extract of Acacia nilotica root. J Intercult Ethnopharmacol. 2016;5(2):6
Journal of Experimental Pharmacology

\section{Publish your work in this journal}

The Journal of Experimental Pharmacology is an international, peerreviewed, open access journal publishing original research, reports, reviews and commentaries on all areas of laboratory and experimental pharmacology. The manuscript management system is completely online and includes a very quick and fair peer-review system. Visit http://www.dovepress.com/testimonials.php to read real quotes from published authors. 